\title{
Resveratrol-supplemented holding or re-culture media improves viability of fresh or vitrified-warmed in vitro-derived bovine embryos
}

\author{
A suplementação dos meios de manutenção ou re-cultivo com resveratrol melhora a viabilidade dle \\ embriões bovinos produzidos in vitro
}

La suplementación de lós médios de mantenimiento o de recultivo com resveratrol mejora La viabilidad de lós embriones bovinos producidos in vitro

Received: 10/00/2021 | Reviewed: 10/00/2021 | Accept: 11/03/2021| Published: 11/05/2021

Arianny Rafaela Neto Silva

ORCID: https://orcid.org/0000-0001-8782-5619

Agência Goiana de Defesa Agropecuária, Brazil

E-mail: arianyrafaella@yahoo.com.br

Thaisa Campos Marques

ORCID: https://orcid.org/0000-0003-1112-6699

University of California, USA

E-mail: thaisacm@hotmail.com

Elisa Caroline Silva Santos

ORCID: https://orcid.org/0000-0001-5717-3541

Universidade Federal de Goias, Brazil

E-mail: elisa_css@hotmail.com

Tiago Omar Diesel

ORCID: https://orcid.org/0000-0002-7796-2414

Universidade Federal de Goias, Brazil

E-mail: tiagodieselvet@gmail.com

Isabelle Matos Macedo

ORCID: https://orcid.org/0000-0002-1204-1833

Universidade Federal de Goias, Brazil

E-mail: isa_belle258@hotmail.com

Rafaela Cavalcanti Teixeira

ORCID: https://orcid.org/0000-0002-0422-0356

Universidade Federal de Goiás, Brazil

E-mail: rafaela.cavalcanti@msn.com

Carlos Frederico Martins

ORCID: https://orcid.org/0000-0001-8551-0146

Embrapa Cerrados, Brazil

E-mail: carlos.martins@embrapa.br

Benner Geraldo Alves

ORCID: https://orcid.org/0000-0001-9465-8054

Ovid Research Company, USA

E-mail: bennervet@gmail.com

Maria Lúcia Gambarini

ORCID: https://orcid.org/0000-0003-0517-7270

Universidade Federal de Goiás, Brazil E-mail: marialucia@ufg.br

\begin{abstract}
The effect of resveratrol supplementation on fresh (E1) or vitrified/warmed (E2) in vitro produced bovine embryos was investigated by evaluating the time-dependent response. After in vitro production, resveratrol $(0.5 \mu \mathrm{M})$ was added to the incubation media and after two incubation periods with or without resveratrol, blastocysts were re-cultured for $24 \mathrm{~h}$. The rates of re-expansion, hatching, total cell number (TCN), apoptotic cells (ACN), reactive oxygen species (ROS) and intracellular glutathione (GSH) content were evaluated. For E1, the re-expansion rate differed at 6 and $10 \mathrm{~h}$ within and between treatments $(\mathrm{P}<0.05)$, as did the re-expansion rate after $24 \mathrm{~h}(\mathrm{P}<0.01)$. The hatching rate increased after $10 \mathrm{~h}$ with resveratrol $(\mathrm{P}<0.01)$ with differences within $(\mathrm{P}<0.05)$, but not between treatments after $24 \mathrm{~h}$ of recultivation. At E2, hatching rate differed between treatments at $24 \mathrm{~h}(\mathrm{P}<0.01)$, with higher TCN in resveratrol-treated blastocysts after 10h $(\mathrm{P}<0.01)$. Resveratrol supplementation reduced ROS generation in E1 and E2 after $10 \mathrm{~h}$ of incubation and increased GSH content $(\mathrm{P}<0.01)$. These results indicate that supplementation of holding re-cultivation medium with resveratrol for treatment of fresh or vitrified/warmed in vitro produced bovine embryos has a positive
\end{abstract}


and time-dependent effect. The reduction of ROS content, the increase of GSH and the anti-apoptotic ability of resveratrol are responsible for its protective effects, allowing an extension of embryo storage time before transfer to recipients.

Keywords: Antioxidant effect; Embryonic development; Holding; In vitro production; Warming.

\section{Resumo}

O efeito da suplementação com resveratrol sobre embriões bovinos produzidos in vitro frescos (E1) ou vitrificados/aquecidos (E2) foi investigado, avaliando a resposta tempo-dependente. Após a produção in vitro, o resveratrol $(0.5 \mu \mathrm{M})$ foi adicionado aos meios de incubação e após dois períodos de incubação com ou sem resveratrol, os blastocistos foram re-cultivados por $24 \mathrm{~h}$. As taxas de reexpansão, eclosão, número total de células (TCN), células apoptóticas (ACN), espécies reativas de oxigênio (ROS) e conteúdo de glutationa intracelular (GSH) foram avaliados. Para E1, a taxa de reexpansão diferiu às 6 e $10 \mathrm{~h}$ dentro e entre tratamentos $(\mathrm{P}<0,05)$, assim como a taxa de reexpansão após $24 \mathrm{~h}(\mathrm{P}<0,01)$. A taxa de eclosão aumentou após $10 \mathrm{~h}$ com resveratrol $(\mathrm{P}<0,01)$ com diferenças dentro $(\mathrm{P}<0,05)$, mas não entre tratamentos após $24 \mathrm{~h}$ de re-cultivo. No E2, a taxa de eclosão diferiu entre tratamentos às $24 \mathrm{~h}(\mathrm{P}<0,01)$, com maior TCN nos blastocistos tratados com resveratrol após $10 \mathrm{~h}(\mathrm{P}<0,01)$. A suplementação com resveratrol reduziu a geração de ROS em E1 e E2 após 10h de incubação e aumentou o conteúdo de GSH (P<0,01). Estes resultados indicam que a suplementação do meio de manutenção ou do meio para re-cultivo com resveratrol para tratamento de embriões bovinos produzidos in vitro frescos ou vitrificados e aquecidos tem um efeito positivo e dependente do tempo. A redução do conteúdo de ROS, o aumento de GSH e a capacidade anti-apoptótica do resveratrol são responsáveis por seus efeitos protetores, permitindo uma extensão do tempo de armazenamento embrionário antes da transferência para as receptoras.

Palavras-chave: Efeito antioxidante; Desenvolvimento embrionário; Manutenção; Produção in vitro; Aquecimento.

\section{Resumen}

Se investigó el efecto de la suplementación con resveratrol en embriones bovinos frescos (E1) o vitrificados/calentados (E2) producidos in vitro, evaluando la respuesta tiempo-dependiente. Tras la producción in vitro, se añadió resveratrol $(0,5 \mu \mathrm{M})$ a los medios y se volvieron a cultivarlos durante $24 \mathrm{hs}$. Se evaluaron las tasas de reexpansión, eclosión, número total de células $(\mathrm{TCN})$, células apoptóticas $(\mathrm{ACN})$, especies reactivas de oxígeno (ROS) y contenido de glutatión (GSH). En E1, la tasa de reexpansión difería a las 6 y 10 hs dentro de los tratamientos y entre ellos $(\mathrm{P}<0,05)$, al igual que la tasa de reexpansión después de 24 hs $(\mathrm{P}<0,01)$. La tasa de eclosión aumentó después de $10 \mathrm{~h}$ con el resveratrol $(\mathrm{P}<0,01)$ con diferencias dentro $(\mathrm{P}<0,05)$, pero no entre los tratamientos después de $24 \mathrm{hs}$ de recultivo. En E2, la tasa de eclosión difería entre los tratamientos a las $24 \mathrm{hs}(\mathrm{P}<0,01)$, con mayor TCN en los blastocistos tratados con resveratrol después de 10hs $(\mathrm{P}<0,01)$. La suplementación con resveratrol redujo la generación de ROS en E1 y E2 tras 10hs de incubación y aumentó el contenido de GSH (P<0,01). Estos resultados indican que la suplementación con resveratrol para el tratamiento de embriones bovinos frescos o vitrificados/calentados tiene un efecto positivo y dependiente del tiempo. La reducción del contenido de ROS, el aumento del GSH y la capacidad antiapoptótica del resveratrol son los responsables de sus efectos protectores, permitiendo prolongar el tiempo de almacenamiento de los embriones antes de su transferencia a las receptoras.

Palabras clave: Efecto antioxidante; Desarrollo embrionario; Mantenimiento; Producción in vitro; Calentamiento.

\section{Introduction}

The increase in human population and the demand for food in the world has served as a stimulus for producers to seek alternatives to increase production over time, and in this context, the bovine in vitro embryo production (IVP) industry has grown considerably worldwide (Sanches et al., 2019). The IVP process involves oocyte maturation, oocyte fertilization, and culture of the in vitro-derived zygote to the blastocyst stage. Cell exposure to high atmospheric $\mathrm{O}_{2}$ levels increases the production of reactive oxygen species (ROS). The manipulation, light temperature, maturation and culture media constituents, sperm, and $\mathrm{O}_{2}$ stress during IVP increases ROS and may lead to a downregulated defense mechanism (Yu et al., 2014). During the entire IVP process, the amount of ROS might imbalance the availability of antioxidants as ROS are produced as a result of cellular metabolism; therefore, ROS levels play a critical role in the success of in vitro fertilization because the quality of the embryo could be impaired owing to harmful effects of the culture environment. The increase in cellular damage because of increased ROS production during the IVP process is well documented (Lee et al., 2012), as well the benefits of adding antioxidant molecules to supplement culture media and thus, decrease ROS production to improve the quality and to protect embryos against damage to DNA and other biomolecules, raising their developmental competence (Morado et al., 2009). 
Pregnancy after the transfer of fresh IVP-derived bovine embryos is less likely than with fresh embryos produced in vivo, and cryopreservation decreases embryo survival (Ferraz et al., 2016). Currently, fresh embryo transfers are the most common choice in IVP; however, when the total embryo production is higher than the number of recipients, or because of the distance from laboratory to farm, an efficient protocol for embryo cryopreservation must be implemented (Sanches et al., 2019). Vitrification is the most efficient cryopreservation method for IVP embryos, which are more sensitive to cryoinjuries than those produced in vivo because, among other factors, they contain more intracellular lipid droplets. Antioxidant additives can improve embryo response to cryopreservation injuries and the benefits of resveratrol, a flavonoid with extra- and intracellular antioxidant properties has been demonstrated in different cellular models and it has the ability to reduce free radical production and to induce the expression of antioxidant genes (Sovernigo et al., 2017). Several studies have shown the beneficial effect of adding resveratrol to the media used for in vitro embryo production, allowing the embryos to recover from low oxidative metabolism (Madrid Gaviria et al., 2018) or their initial quality after cryopreservation (Madrid Gaviria et al., 2019) (Hara, Kim \& Aoki, 2018). This improvement was also associated with improved embryo tolerance to cryopreservation by slow freezing (Hayashi et al., 2019) and by vitrification (Hayashi et al., 2018), including of the oocytes (Wang et al., 2014; Spricigo et al., 2017). Bovine embryos vitrified in the stage of 8-12 cells and and treated with resveratrol after warming showed improved development during the re-culture for 5 days (Hara, Kim \& Aoki, 2018). However, owing to the growing demand for in vitro-derived bovine embryos, the addition of different products and molecules in the culture or holding media to improve post-culture viability of embryos easily and safely must be available to the field technician, because the conditions on the farm are not the same as in the IVP research or commercial production laboratory. To the best of our knowledge there are no studies showing the effect of adding resveratrol to the holding medium for fresh or vitrified-warmed in vitro-derived bovine embryos in the blastocyst phase. This study was designed based on the hypothesis that it is possible to improve the quality of fresh and vitrified-warmed IVP-derived bovine embryos in the pre-preincubation period, using the practical approach of adding resveratrol from a stock solution to the holding or in vitro culture (IVC) media.

\section{Methodology}

The experiments were developed as a quantitative laboratory research (Pereira et al. 2018). All experimental procedures were approved by the Ethics Committee on Animal Experimentation/Federal University of Goias, protocol \#049/2015.

Unless otherwise indicated, all media for oocyte maturation, fertilization, embryo culture, and embryo cryopreservation were prepared by Progest ${ }^{\circledR}$ Animal Biotechnology (Botucatu, SP, Brazil).

\section{Experimental design}

The experimental design was completely randomized. Time-responsive effects of resveratrol on fresh (E1) and vitrified-warmed (E2) in vitro-derived blastocysts' developmental competencies were evaluated. Resveratrol was added to the incubation medium at a concentration of $0.5 \mu \mathrm{M}$. As control, a group of blastocysts were incubated in the absence of resveratrol. After the two incubation periods with or without resveratrol, blastocysts were re-cultured in the standard in vitro culture medium for up to $24 \mathrm{~h}$. Blastocyst re-expansion and hatching rates were evaluated as developmental parameters and the number of total cells, apoptotic cells, ROS, and intracellular glutathione (GSH) content were assessed. 


\section{Experimental Procedures}

\section{In vitro embryo production (E1 and E2)}

The IVP was performed as previously reported (Marques et al., 2018). Briefly, bovine ovaries were collected from local slaughterhouses, and cumulus-oocyte complexes (COCs; $n=1,500 ; 10$ replicates) were aspirated from follicles between 3 and $8 \mathrm{~mm}$ in diameter. GI and GII oocytes (defined as more than three compact layers of cumulus cells and homogeneous cytoplasm and two compact layers of cumulus cells with less homogeneous cytoplasm in relation to the previous one, respectively) were subjected to the in vitro maturation process in groups of 30-35 COCs, matured in drops of IVC medium for 22-24 h at $38.5{ }^{\circ} \mathrm{C}$ in $5 \% \mathrm{CO}_{2}$ and saturated relative humidity without condensation. After maturation, COCs were incubated with conventional commercial frozen semen from a single Nellore bull with tested in vitro fertility and embryo production followed the previously reported routine (Marques et al., 2018). Probable zygotes remained for 7 days (D7) in drops of IVC medium at $38.5{ }^{\circ} \mathrm{C}$ in $5 \% \mathrm{CO}_{2}$. Morphological assessment of embryo quality was performed according to Bó and Mapletoft (2013). Development to the blastocyst stage was evaluated on D7 and fresh blastocysts were immediately subjected to the treatments (E1) or vitrified using open pulled straws (E2).

\section{Resveratrol solution}

Resveratrol (3,4',5-trihydroxy-trans-stilbene, Sigma-Aldrich Chemical, St. Louis, MO, USA) 5.0 mM was prepared as a stock solution by dissolving resveratrol in ethanol (Sigma-Aldrich Chemical), stored in $10.0 \mu \mathrm{L}$ aliquots, and kept frozen until use. The $0.5 \mu \mathrm{M}$ concentration was obtained by dilution in the media according to the volume to be used. The final concentration was selected based on previously reported results showing an increase in the number of transferable bovine embryos using low concentrations of resveratrol during in vitro culture (Salzano et al., 2014).

\section{Experiment 1- Growing in straw in holding medium}

Six replicates were established with 307 D7-fresh Code 1 and 2 blastocysts. The blastocysts were placed in the holding medium with or without resveratrol $0.5 \mu \mathrm{M}$ (Resv) and packed into $0.25 \mathrm{~mL}$ plastic straws. Straws were sealed and placed on a heating plate and kept at $36{ }^{\circ} \mathrm{C}$ for 6 and $10 \mathrm{~h}$. At the end of the incubation period, embryos were evaluated for expansion rates, hatching, and quality. Embryos were then placed again in culture medium and re-cultured up to $24 \mathrm{~h}\left(38.5{ }^{\circ} \mathrm{C}\right.$ in $5 \% \mathrm{CO}_{2}$ ). Incubation time was defined by the average time required to transport the fresh embryos from the laboratory to the farm. The two time points were selected based on a previous simulation performed in our laboratory.

\section{Experiment 2 - Vitrification, warming, re-cultivation}

Eight replicates were set up with 411 D7-fresh Code 1 and 2 blastocysts which were subjected to the vitrification protocol (Marques et al., 2018) using buffered HEPES with TCM-199 supplemented with 20\% bovine fetal serum; $7.5 \%$ ethylene glycol and 7.5\% dimethyl sulfoxide; and 15\% ethylene glycol, 15\% dimethyl sulfoxide, and $0.5 \mathrm{M}$ sucrose. Embryos were loaded in open pulled straws (Vitri-Ingá@ INGAMED, Maringá, PR), which were immersed in liquid nitrogen and stored in cryogenic cylinders for 60 days. Subsequently, the embryos were warmed on a heating plate at $38{ }^{\circ} \mathrm{C}$ and cultured in $200 \mu \mathrm{L}$ drops of IVC medium (5-7 embryos/droplet; $38.5{ }^{\circ} \mathrm{C}$ in $5 \% \mathrm{CO}_{2}$ ) without (Control) and with resveratrol $0.5 \mu \mathrm{M}(\mathrm{Resv})$. Embryo viability was recorded at 6 and $24 \mathrm{~h}$ after warming by evaluating the rate of embryos that re-expanded to the original size and developed to a hatching blastocyst. Incubation time for the cultivation after warming was based on previous studies showing the beneficial effect of using resveratrol during some steps of the embryo production on the viability of previously vitrified-warmed embryos after $24 \mathrm{~h}$ of post-warming culture (Salzano et al., 2014). The two time points were selected based on a previous transport simulation performed in our laboratory. 


\section{Detection of cellular apoptosis, ROS generation, and GSH levels}

For the evaluations using fluorescent probes, 10 blastocysts from each treatment (Control and Resv) and incubation time $(6$ and $10 \mathrm{~h})$ from E1 and 15 blastocysts from each treatment (Control and Resv) and incubation time (6 and $24 \mathrm{~h})$ from E2 were analyzed.

The total cell number (TCN) and number of apoptotic cells $(\mathrm{ACN})$ were evaluated with the terminal deoxynucleotidyl transferase-mediated dUTP nick end labeling (TUNEL) assay using the In Situ Cell Death Detection Kit (Roche, Mannheim, Germany), according to the manufacturer's instructions. The nuclei of TUNEL-positive cells (fragmented DNA) were visualized at $450 \mathrm{~nm}$ (green), and all nuclei were visualized at $365 \mathrm{~nm}$ (blue). All cells labeled and visualized at both wavelengths were counted to determine the mean TCN and ACN. Intracellular ROS and GSH content were measured using dichlorohydrofluorescein diacetate (C400, Molecular Probes), and 4-chloromethyl-6,8-difluoro-7-hydroxycoumarin (CellTracker Blue CMF2HC, Molecular Probes), respectively, as previously reported (Marques et al., 2021). ROS was detected as green (460 $\mathrm{nm}$ wavelength) and GSH as blue (370 nm wavelength) fluorescence, and to evaluate ROS levels and GSH content, the relative fluorescence intensity was considered directly proportional to intracellular ROS levels and GSH content.

Embryos were evaluated using epifluorescence microscopy (Olympus BX43, Tokyo, Japan), and images were captured using a camera (Olympus SC30, Tokyo, Japan) and saved in a TIFF format. The fluorescence intensities of the embryos were analyzed individually using Image J software (version 1.46; National Institutes of Health, Bethesda, MD) and normalized to those of the Control group.

\section{Statistical analysis}

All statistical analyses were performed using Sigma Plot 11.0 (Systat Software Inc, EUA). Data were first checked for normal distribution (Shapiro-Wilk test). Embryonic development and rates of re-expansion and hatching were compared using Fischer's chi-square test. The TCN and ACN were compared using the Kruskal-Wallis test. The Mann-Whitney test was used to analyze intracellular ROS and GSH levels. Data are presented as mean $( \pm$ SEM) and percentage. Differences $\leq 0.05$ were considered significant.

\section{Results}

A total of 1,020 embryos were produced from 1,500 oocytes (68\% success); 718 (70.4\%) were morphologically classified as Code 1 and Code 2 (Bó \& Mapletoft, 2013) and used for the two experiments.

\section{Experiment 1}

The results of resveratrol $0.5 \mu \mathrm{M}$ treatment on fresh in vitro-derived bovine embryos are presented in Table 1 . The reexpansion rate was calculated on the number of viable embryos and hatching rate was calculated on the number of embryos expanded within each moment. Incubation for $10 \mathrm{~h}$ improved embryo re-expansion and hatching in both treatments (Control, $28.9 \%$ and Resv, 23.3\%, $\mathrm{P}<0.05$ ). After the re-cultivation period of $24 \mathrm{~h}$, the highest re-expansion rate was achieved in the Resv $10 \mathrm{~h}$ embryos $(36.6 \%, P<0.05)$ and the hatched rate differed $(\mathrm{P}<0.05)$ after $10 \mathrm{~h}$ (Control, $20.6 \%$ and Resv, 36.6\%). Embryos incubated for $6 \mathrm{~h}$ before the re-cultivation of up to $24 \mathrm{~h}$ presented a higher hatched rate (Control, $43.3 \%$ and Resv, $48.4 \%)$ at the final time than those incubated for $10 \mathrm{~h}$ (Control, $25.0 \%$ and Resv, $27.2 \%$; $\mathrm{P}<0.05$ ). 
Table 1. Re-expansion and hatched rates of fresh in vitro-derived embryos after exposed or not to a holding medium with Resveratrol $0.5 \mu \mathrm{M}$ and re-cultured in IVC medium up to $24 \mathrm{~h}$.

\begin{tabular}{|c|c|c|c|c|c|}
\hline \multirow[b]{2}{*}{ Treatment } & \multirow[b]{2}{*}{$\mathrm{n}$} & \multicolumn{2}{|c|}{ Re-expansion $(\%)$} & \multicolumn{2}{|c|}{ Hatched (\%) } \\
\hline & & 6 hours & 24 hours & 6 hours & 24 hours \\
\hline Holding $6 \mathrm{~h}$ & 81 & $28.9(20 / 69)^{\mathrm{a}}$ & $54.5(30 / 55)^{\mathrm{a}}$ & - & $43.3(13 / 30)^{\mathrm{a}}$ \\
\hline \multirow[t]{2}{*}{ Resveratrol 6 h } & 86 & $23.3(18 / 77)^{\mathrm{a}}$ & $48.5(33 / 68)^{\mathrm{a}}$ & - & $48.4(16 / 33)^{\mathrm{a}}$ \\
\hline & & 10 hours & 24 hours & 10 hours & 24 hours \\
\hline Holding $10 \mathrm{~h}$ & 88 & $43.2(29 / 67)^{b}$ & $62.0(36 / 58)^{\mathrm{a}}$ & $20.6(6 / 29)^{\mathrm{a}}$ & $25.0(9 / 36)^{b}$ \\
\hline Resveratrol $10 \mathrm{~h}$ & 52 & $57.6(30 / 52)^{\mathrm{c}}$ & $80.4(33 / 41)^{b}$ & $36.6(11 / 30)^{\mathrm{b}}$ & $27.2(9 / 33)^{\mathrm{b}}$ \\
\hline
\end{tabular}

a,b,c Within a column, values without a common letter differed between and within treatments $(P<0.05)$.

Source: Authors.

There was an effect of treatment and incubation time on TCN (Figure 1, Figure 2) within the same incubation time. Control and Resv embryos differed regarding TCN [Control 6 h, $118.1 \pm 3.2$ versus Resv 6 h, $129.1 \pm 2.5$ (P<0.001) and Control 10 h, $82.4 \pm 2.5$ versus Resv 10 h, $114.8 \pm 1.9(P<0.001)]$. Comparison between treatments showed a lower ACN in Resv $6 \mathrm{~h}(11.8 \pm 1.0)$ and Resv $10 \mathrm{~h}$ embryos $(11.0 \pm 1.2)$ than in Control $6 \mathrm{~h}(15.0 \pm 1.2)$ and Control $10 \mathrm{~h}(14.8 \pm 1.2 ; \mathrm{P}<$ $0.05)$.

Figure 1. Mean ( \pm SEM) number of total cells (a) and apoptotic cells (b) recorded in in vitro-derived embryos exposed (6 or 10 hours) to medium with or without supplementation of Resveratrol $(0.5 \mu \mathrm{M})$ and re-cultured in IVC medium up to $24 \mathrm{~h}$.

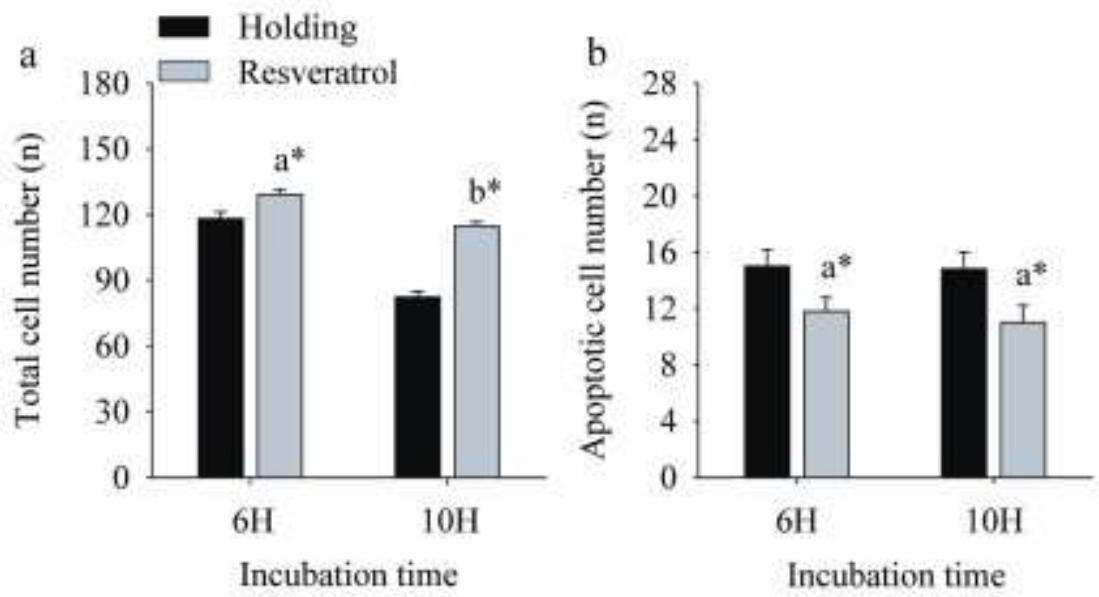

a,b Values without a common letter differed between Resveratrol $6 \mathrm{H}$ and $10 \mathrm{H}(P<0.05)$.

${ }^{*}$ Differ from the holding medium (control) within the same incubation time $(P<0.05)$.

Source: Authors. 
Figure 2. Representative images of TUNEL staining recorded in in vitro-derived embryos exposed (6 or 10 hours) to Holding medium with or without supplementation of Resveratrol $(0.5 \mu \mathrm{M})$ and re-cultured in IVC medium up to 24 h. The nuclei of TUNEL-positive cells (fragmented DNA, green), and all nuclei (blue), fluorescence microscopic imaging.

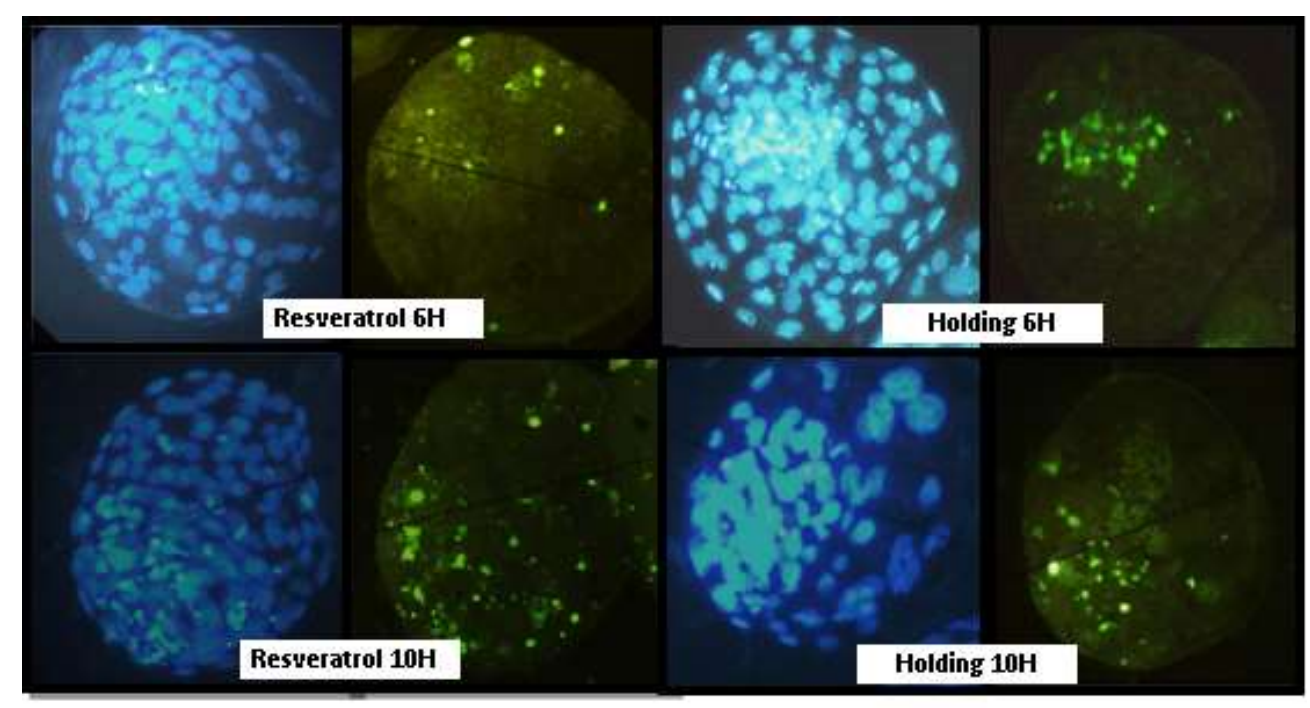

Source: Authors.

The levels of intracellular ROS and GSH are shown in Figure 3. ROS differed between and within treatments $(\mathrm{P}<$ $0.01)$ irrespective of incubation time. Resv $6 \mathrm{~h}$ produced more ROS than Resv $10 \mathrm{~h}(\mathrm{P}<0.01)$. GSH content was higher in the Resv $6 \mathrm{~h}$ embryos, followed by that in Resv $10 \mathrm{~h}$ and Control $10 \mathrm{~h}(\mathrm{P}<0.01)$. After defining the fluorescence emission from Control embryos as “1," ROS and GSH of Resv embryos were $0.65 \pm 0.1$ and $1.3 \pm 0.1$, respectively.

Figure 3. Mean ( \pm SEM) (a) reactive oxygen species (ROS) and (b) glutathione peroxidase (GSH) recorded in in vitro-derived embryos exposed (6 or 10 hours) to medium with or without supplementation of Resveratrol $(0.5 \mu \mathrm{M})$ and re-cultured in IVC medium up to $24 \mathrm{~h}$.Fluorescence intensity in the control group was defined as 1.0 .
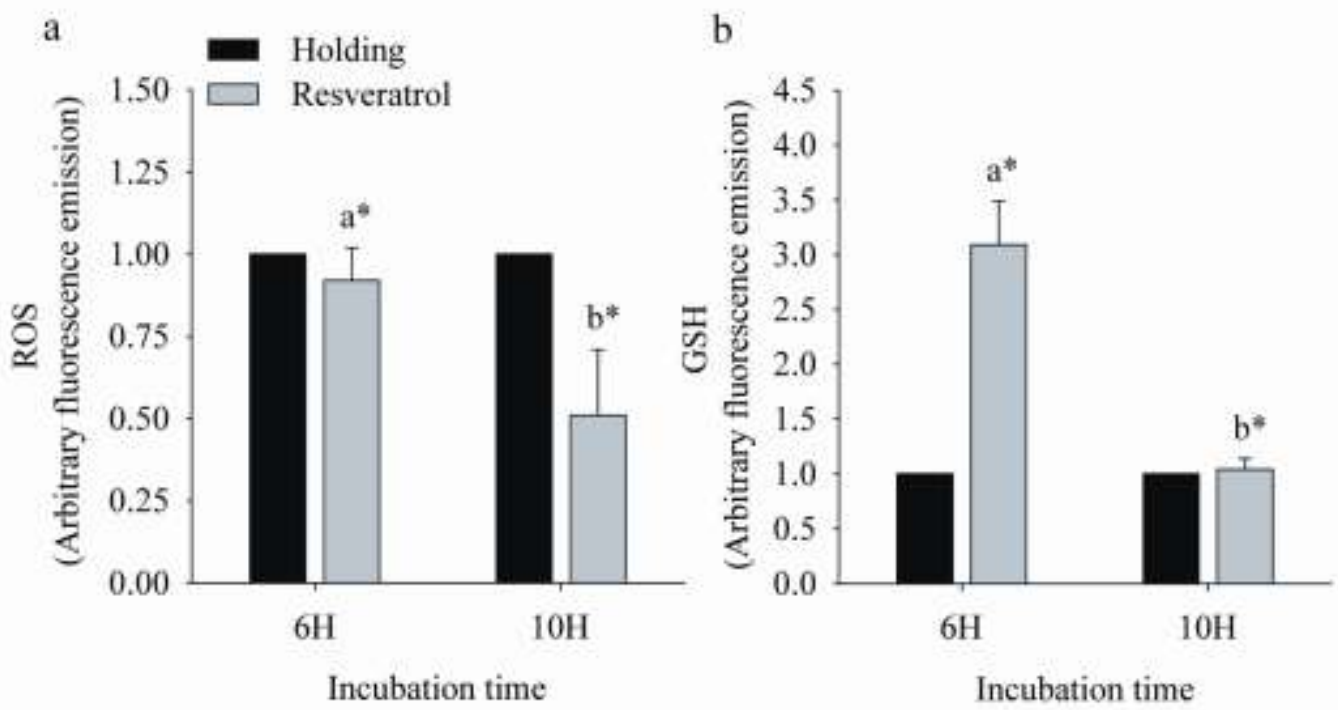

\footnotetext{
.${ }^{\mathrm{a}, \mathrm{b}}$ Values without a common letter differed between Resveratrol $6 \mathrm{H}$ and $10 \mathrm{H}(P<0.05) .{ }^{*}$ Differ from the holding medium (control) within the same incubation time $(P<0.05)$.

Source: Authors.
} 


\section{Experiment 2}

The results of resveratrol $0.5 \mu \mathrm{M}$ treatment on vitrified in vitro-derived bovine embryos after warming and recultivation are presented in Table 2 and Figure 4, 5 and 6. The hatching rate in the Resv embryos was higher (37.7\%) than in the Control $(19.1 \%)$ after $24 \mathrm{~h}$ of incubation $(\mathrm{P}<0.01)$.

Table 2. Re-expansion and hatched rates of vitrified in vitro-derived bovine embryos warmed and re-cultured exposed or not to a medium with Resveratrol $0.5 \mu \mathrm{M}$ during 6 or $24 \mathrm{hs}$.

\begin{tabular}{llllll}
\hline & \multicolumn{3}{l}{ Re-expansion $(\%)$} & Hatched $(\%)$ & \\
\cline { 3 - 6 } Treatment & $\mathrm{n}$ & $6 \mathrm{hs}$ & $24 \mathrm{hs}$ & $6 \mathrm{hs}$ & $24 \mathrm{hs}$ \\
\hline Control & 200 & $38.3(41 / 107)^{\mathrm{a}}$ & $56.6(47 / 83)^{\mathrm{a}}$ & $14.6(6 / 41)^{\mathrm{a}}$ & $19.1(9 / 47)^{\mathrm{a}}$ \\
Resveratrol & 211 & $37.5(45 / 120)^{\mathrm{a}}$ & $51.9(53 / 102)^{\mathrm{a}}$ & $13.3(6 / 45)^{\mathrm{a}}$ & $37.7(20 / 53)^{\mathrm{b}}$ \\
\hline
\end{tabular}

a,b Within a column, values without a common letter differed among treatments $(\mathrm{P}<0.01)$. Source: Authors.

For TCN and ACN evaluation, an additional group of 15 fresh embryos was included (Figure 4, Figure 5) to avoid errors in data interpretation. These variables were affected by vitrification, as evidenced by the differences regarding the above-mentioned parameters. Fresh embryos presented more TCN (131.6 \pm 2.4$)$ and fewer ACN (6.3 \pm 0.8$)$ than vitrified embryos $(\mathrm{P}<0.01)$, irrespective of treatments. The TCN $(102.7 \pm 2.3)$ and $\mathrm{ACN}(11.5 \pm 1.0)$ was affected by the addition of resveratrol in comparison to the Control $(88.8 \pm 2.5$ and $23.6 \pm 1.0$, respectively; $\mathrm{P}<0.01)$. Resveratrol decreased intracellular ROS levels and increased GSH content (Fig. 6) in comparison with that in the Control $(P<0.01)$. As the fluorescence emission was defined as "1," normalized ROS levels and GSH content were $0.65 \pm 0.1$ and $1.3 \pm 0.1$, respectively.

Figure 4. Mean $( \pm$ SEM) number of total cells $(\mathrm{TCN})$ and apoptotic cells $(\mathrm{ACN})$ recorded in vitrified in vitro-derived embryos warmed and re-cultured in a medium supplemented or not with Resveratrol.

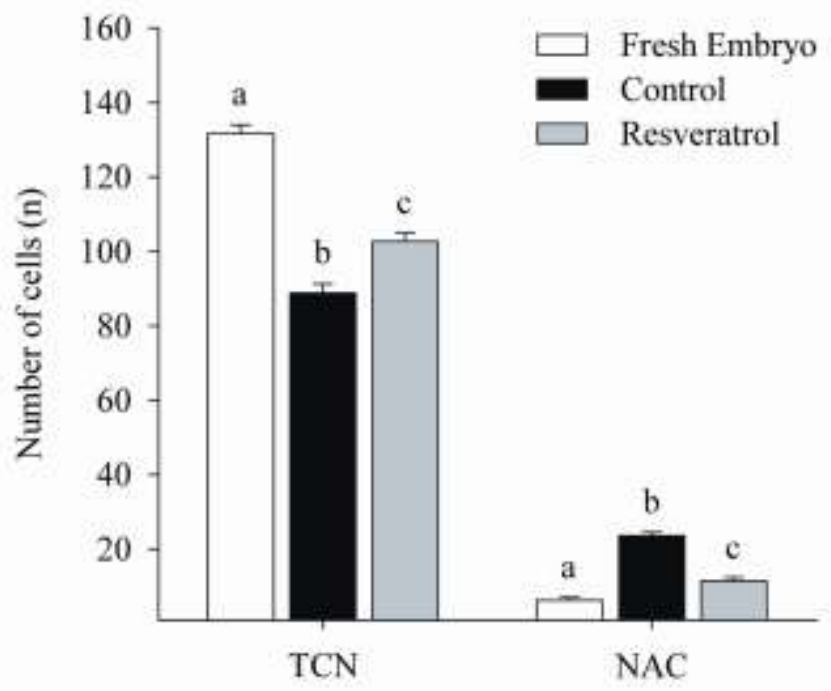

a,b,c Values without a common letter differed within the same parameter evaluated $(P<0.05)$.

Source: Authors. 
Figure 5. Representative images of TUNEL staining recorded in vitrified in vitro-derived embryos warmed and re-cultured in a medium supplemented or not with Resveratrol $(0.5 \mu \mathrm{M})$ up to $24 \mathrm{~h}$. The nuclei of TUNEL-positive cells (fragmented DNA, green), and all nuclei (blue), fluorescence microscopic imaging.

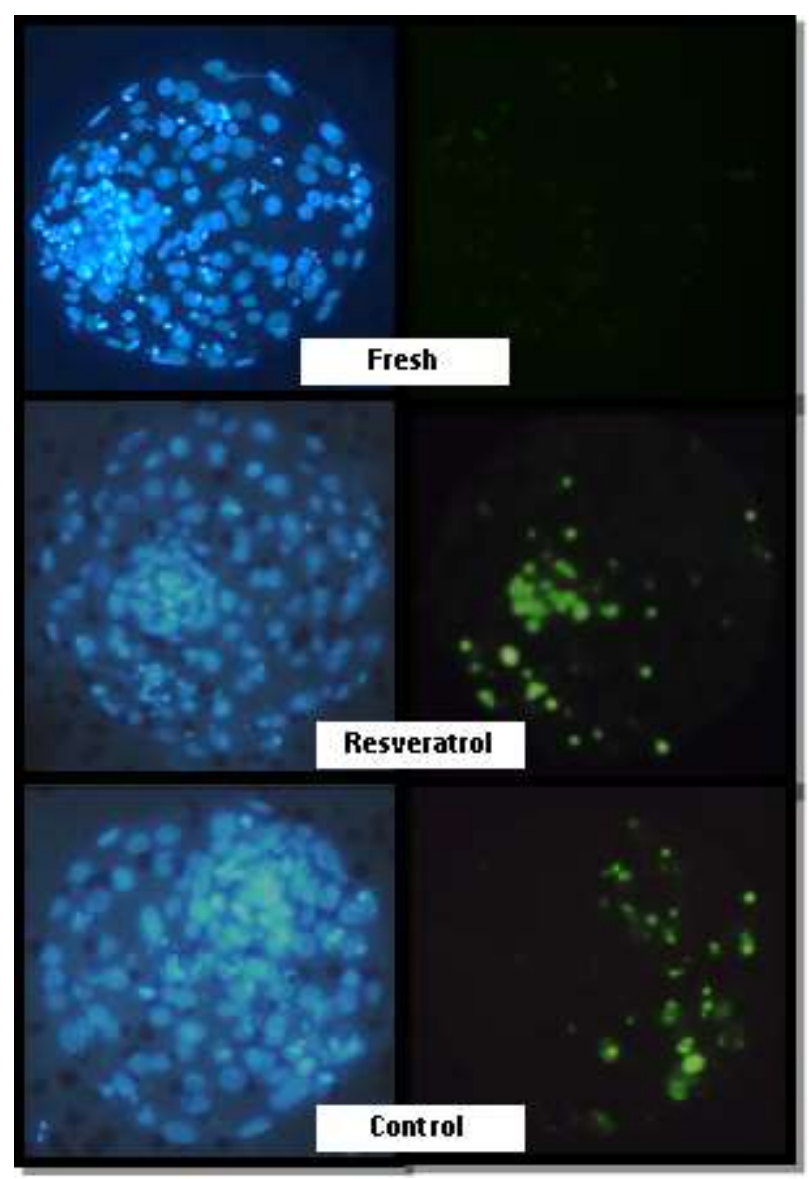

Source: Authors.

Figure 6. Mean $( \pm$ SEM) reactive oxygen species (ROS) and glutathione peroxidase (GSH) recorded in vitrified in vitroderived embryos warmed and re-cultured in a medium supplemented or not with Resveratrol. Fluorescence intensity in the control group was defined as 1.0 .

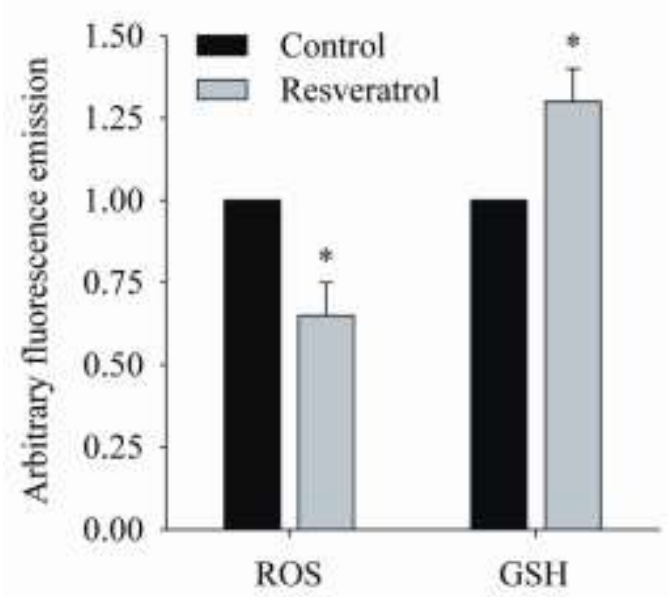

*Differ from the control within the same parameter evaluated $(P<0.05)$. Source: Authors. 


\section{Discussion}

Bovine IVP embryos present increased susceptibility with storage during transportation to the farm and to cryological damage and the result is reduced pregnancy rates after transfer (Hansen et al., 2010). Our main findings regarding bovine IVP embryos were that (i) the quality of fresh embryos incubated in a holding medium supplemented with resveratrol might be improved and (ii) post-warming viability can be enhanced by incubation of the embryos with resveratrol. The IVP bovine embryos are less developmentally competent and presented a poorer quality than in vivo-derived embryos [18]. Developmental ability and quality are associated with cryosurvival and pregnancy and can be explained by morphological, functional, cellular, and molecular competencies of the embryos [19]. In vitro survival of fresh IVP embryos plays an important role because pregnancy rates for cows receiving fresh embryos are higher than in those receiving cryopreserved embryos (Bó \& Mapletoft, 2013). The transportation in portable incubators and maintenance of the embryos in a hypothermic medium at refrigeration temperature (Cavalieri et al., 2015; Ideta e al., 2013) have been suggested as alternatives to minimize the problem, as embryo viability and pregnancy rate may be influenced by the time spent in transportation Marinho et al., 2012). Embryonic stage at the time of packing (expanded or initial blastocyst), but not the time of transportation (6 or 9 h), was shown to influence hatching and degeneration rates Silveira et al., 2020). We proposed a short exposure period to a low concentration of resveratrol to improve developmental competence and quality of in vitro-derived embryos and to prevent oxidative stress during two important steps of embryo transfer - the transportation to the farm and post warming period.

\section{Re-expansion and hatching rates}

In E1, the evaluation at $10 \mathrm{~h}$ of incubation showed that Resv increased re-expansion by $14.4 \%$ and hatching rates by $16.0 \%(\mathrm{P}<0.05)$. Re-expansion rate is a good morphological indicator of embryo quality and the hatching rate is a biomarker of the quality and developmental capacity of blastocysts and has been used to determine the efficiency of embryo preservation methods (Do et al., 2018). In E2, Resv improved the re-expansion rate at 6 and $24 \mathrm{~h}$ of re-cultivation. The hatching rate was $18.6 \%$ higher $(\mathrm{P}<0.01)$ for resveratrol than in the Control after re-cultivation. Hatching is a pre-requisite for uterine attachment and placentation of the pre-implantation embryo, and failures lead to pregnancy loss (Taniyama et al., 2011). Hatching rate may be impaired in cryopreserved embryos owing to the occurrence of zona pellucida hardening (Taniyama et al., 2011).

\section{Cell number counting}

In E1, TCN in the Control was lower than in Resv, irrespective of incubation time before the re-cultivation. The TCN of fresh D7 IVP-derived bovine embryo evaluated without any additional treatment ranged from 84.6 (Mori, Otoi \& Suzuki, 2008) to 119 (Block, Bonilla \& Hansen, 2010). Our results for Resv 10 h are similar to those of another study (114.8, Block, Bonilla \& Hansen, 2010), representing an improvement in embryo quality, especially because these parameters were recorded after $24 \mathrm{~h}(10 \mathrm{~h}$ in the straw on the heating plate and $14 \mathrm{~h}$ of re-cultivation in the incubator). Embryo cell number indicates the viability of pre-implantation embryos (Papaioannou \& Ebert, 1988). On day 14, the bovine embryos develop an embryonic disc, but approximately $25 \%$ of in vitro embryos fail to reach this stage (Block et al. ,2007); reduction in the apoptotic cells might improve the proportion of bovine embryos developing an embryonic disc (Block, Bonilla \& Hansen, 2010). As differences in ACN were observed, results regarding cell counting for Resv embryos indicate an improvement in their quality. Vitrified IVP bovine embryos suffer additional cellular damage, presenting reduced cellular numbers. In E2, this was evident by the TCN in fresh (131.6) and vitrified embryos, disregarding the resveratrol IVC supplementation (Fig. 4, Fig. 5). The difference between TCN of the Control (88.8) and Resv (102.7) vitrified-warmed embryos was significant $(P<0.05)$, clearly owing to the reduction in apoptotic cells (ACN, 23.6 for Control and 11.5 for Resv), which probably contributed toward maintaining the inner cell mass number, increasing their viability. Apoptosis is a normal process during the pre-implantation 
period to eliminate abnormal cells; the viability of vitrified embryos after warming is affected because of the cellular loss in the inner cell mass. Decreased inner cell mass and trophectodermal cell number in vitrified embryos probably cause placentary alterations, impacting pregnancy rates after in vitro embryo manipulation (Ufer et al.,2010).

\section{ROS and GHS}

In E1, ROS was similar between Control and Resv 6 h; however, a significant decrease $(\mathrm{P}<0.01)$ was verified in the Resv $10 \mathrm{~h}$ embryos. Inversely, GSH intracellular content was higher in Resv $6 \mathrm{~h}(P<0.01)$. Poor quality of embryos has been associated with ROS generation, leading to damage because of oxidative stress caused by the imbalance between pro- and antioxidants (Al-Gubory, Fowler \& Garrel, 2010). ROS production increases up to the late morula stage during embryo in vitro culture and decreases in expanded blastocysts until values similar to those in oocytes are observed (Dalvit et al., 2005). The higher lipid content of IVP embryos induces higher ROS levels than in their in vivo counterparts, and culture media composition influences these factors (Romek et al., 2010). As our study was focused on the embryo response to extended incubation in the holding medium, the present results regarding ROS level and GSH content indicate advantages with the addition of resveratrol. Vitrification results in cellular and subcellular damage, which is gradually restored over a $24 \mathrm{~h}$ period. ROS modifies proteins and other macromolecules but are vital to signaling molecules within cells (Ufer et al., 2010). Intracellular content of ROS was 35\% lower in the Resv embryos during the $24 \mathrm{~h}$ of the re-cultivation period than in the Control embryos $(\mathrm{P}<0.01)$, confirming the protective effect of this antioxidant. Resveratrol maintains the cellular redox state, protecting the cell against oxidative injuries, and has been added to in vitro maturation culture media to produce bovine embryos with improved oocyte development and embryo competence and to improve cryotolerance of bovine IVP embryos (Silveira et al., 2020). ROS causes mitochondrial damage in oocyte and embryos; the mitochondria are vulnerable during early cleavage, and their maturation during in vitro culture may be incomplete, leading to inadequate coupling efficiency during blastocyst development. Resveratrol, as an activator of sirtuin deacetylases, which regulates proper mitochondrial function, enhances embryo quality through its action on mitochondrial maturation during embryonic development (Cagnone \& Sirard, 2016). The GSH content was higher in the Resv embryos than in Control embryos $(P<0.01)$. GSH protects the cell from oxidative damage and regulates the intracellular redox balance, playing an important role in DNA repair, protein synthesis, and cell proliferation during embryo development and the level of GSH serves as a marker of embryo developmental competence. The re-cultivation of vitrified-thawed embryos during a period of 3 to $16 \mathrm{~h}$ could be an alternative to improve embryo recovery before the transfer to a recipient (Nedambale et al., 2006). We tested a re-cultivation period of $24 \mathrm{~h}$ after warming and verified a potential positive effect of this procedure using resveratrol as a practical alternative for field technicians, because embryos could be warmed and subjected to a re-culture in IVC media during transportation using portable incubators.

\section{Final Considerations}

Our findings suggest a time-dependent effect of a low concentration of resveratrol for both fresh and vitrified-warmed bovine embryos on the embryo quality regarding hatching rates, cell loss, and oxidative stress recovery, allowing the embryos to restore their developmental competence. In future, studies will be performed to investigate the phenotype of embryo developmental competence and quality and the pregnancy rate resulting from the use of these proposed strategies.

\section{Acknowledgements}

The authors are grateful to FAPEG for a scholarship granted to the first author. ML Gambarini was supported by CNPq. 


\section{References}

Al-Gubory, K. H., Fowler, P. A., \& Garrel, C. (2010). The roles of cellular reactive oxygen species, oxidative stress and antioxidants in pregnancy outcomes. International Journal of Biochememistry and Cell Biology, 42, 1634-50.

Block, J., Bonilla, L., \& Hansen, P. J. (2010). Efficacy of in vitro embryo transfer in lactating dairy cows using fresh or vitrified embryos produced in a novel embryo culture medium. Journal of Dairy Science, 93, 5234-42.

Block, J., Fischer-Brown, A. E., Rodina, T. M., Ealy, A. D., \& Hansen, P. J. (2007). The effect of in vitro treatment of bovine embryos with IGF-1 on subsequent development in utero to day 14 of gestation. Theriogenology, 68, 153-61.

Bó, G., \& Mapletoft, R. J. (2013). Evaluation and classification of bovine embryos. Animal Reproduction, 10, 344-8.

Cagnone, G., \& Sirard, M. A. (2016). The embryonic stress response to in vitro culture: insight from genomic analysis. Reproduction, 152, 247-61.

Cavalieri, F. L. B., Andreazzi, M. A., Colombo, A. H. B., Emanuelli, I. P., Moreski, D. A. B., \& Silva, W. M. (2015). Studies on in vitro bovine embryos during their transport. Ars Veterinaria, 31, 7-11. https://doi: 10.15361/2175-0106.2015v31n1p07-11.

Dalvit, G. C., Cetica, P. D., Pintos, L. N., \& Beconi, M. T. (2005). Reactive oxygen species in bovine embryo in vitro production. Biocell , $29,209-12$.

Do, V. H., Catt, S., Amaya, G., Batsiokis, M., Walton, S., \& Taylor-Robinson, A. W. (2018). Comparison of pregnancy in cattle when non-vitrified and vitrified in vitro-derived embryos are transferred into recipients. Theriogenology, 15, 105-10.

Ferraz, P. A., Burnley, C., Karanjam, J., Vieira-Neto, A., Santos, J. E., Chebel, R. C., \& Galvão, K. N. (2016). Factors affecting the success of a large embryo transfer program in Holstein cattle in a commercial herd in the southeast region of the United States. Theriogenology, 86, $1834-41$.

Hansen, P. J., Block, J., Loureiro, B., Bonilla, L., \& Hendricks, K. E. M. (2010). Effects of gamete source and culture conditions on the competence of in vitro-produced embryos for post-transfer survival in cattle. Reproduction, Fertility, Development, 22, 59-66.

Hara, T., Kin, A., Aoki, S., Nakamura, S., Shirasuna, K., Kuwayama, T., \& Iwata, H. (2018). Resveratrol enhances the clearance of mitochondrial damage by vitrification and improves the development of vitrified-warmed bovine embryos. PloS One, 13(10), e0204571.

Hayashi, T., Kansaku, K., Abe, T., Ueda, S., \& Iwata, H. (2019). Effects of Resveratrol treatment on mitochondria and subsequent embryonic development of bovine blastocysts cryopreserved by slow freezing. Animal Science Journal, 90, 849-856.

Hayashi, T., Ueda, S., Mori, M., Baba, T., Abe, T., \& Iwata, H. (2018). Influence of Resveratrol pretreatment on thawed bovine embryo quality and mitochondrial DNA copy number. Theriogenology, 106, 271-78.

Ideta, A., Aoyagi, Y., Tsuchiya, K., Kamijima, T., Nishimiya, Y., \& Tsuda, S. (2013). A simple medium enables bovine embryos to be held for seven days at $4^{\circ} \mathrm{C}$. Science Reproduction, 3, 1173. https://doi.org/10.1038/srep01173

Lee, T. H., Lee, M. S., Liu, C. H., Tsao, H. M., Huang, C. C., \& Yang, Y. S. (2012). The association between microenvironmental reactive oxygen species and embryo development in assisted reproduction technology cycles. Reproduction Science, 19, 725-32.

Madrid Gaviria, S., López Herrera, A., Urrego, R., Restrepo Betancur, G., \& Echeverri Zuluaga, J. J. (2019). Effect of Resveratrol on vitrified in vitro produced bovine embryos: Recovering the initial quality. Cryobiology, 89, 42-50.

Madrid Gaviria, S., Morado, S. A., López Herrera, A., Restrepo Betancur, G., Urrego, R., Echeverri Zuluaga, J., \& Cética, P. D. (2018). Resveratrol supplementation promotes recovery of lower oxidative metabolism after vitrification and warming of invitro-produced bovine embryos. Reproduction, Fertility, Development, 31, 521-528.

Marinho, L. S. R., Untura, R. M., Morotti, F., Moino, L. L., Rigo, A. G., Sanches, B. V., Pontes, J. H. F., Seneda, M. M. (2012). Large-scale programs for recipients of in vitro-produced embryos. Animal Reproduction, 9, 323-8.

Marques, T. C., Silva, E. C., Diesel, T. O., Leme, L. O., Martins, C. F., Dode, M., Alves, B. G., Costa, F., de Oliveira, E. B., \& Gambarini, M. L. (2018). Melatonin reduces apoptotic cells, SOD2 and HSPB1 and improves the in vitro production and quality of bovine blastocysts. Reproduction in Domestic Animals, 53, 226-36.

Marques, T. C., Santos, E., Diesel, T. O., Martins, C. F., Cumpa, H., Leme, L. O., Dode, M., Alves, B. G., Costa, F., Oliveira, E. B., \& Gambarini, M. L. (2021). Blastocoel fluid removal and melatonin supplementation in the culture medium improve the viability of vitrified bovine embryos. Theriogenology, 160, 134-141. https://doi.org/10.1016/j.theriogenology.2020.10.028

Marsico, T. V., Camargo, J., Valente, R. S., \& Sudano, M. J. (2019). Embryo competence and cryosurvival: Molecular and cellular features. Animal Reproduction, 16, 423-39. https://doi.org/10.21451/1984-3143-ar2019-0072.

Morado, S. A., Cetica, P. D., Beconi, M. T., \& Dalvit, G. C. (2009). Reactive oxygen species in bovine oocyte maturation in vitro. Reproduction, Fertility, Development, 21, 608-14.

Mori M, Otoi T, \& Suzuki T. (2008). Correlation between the Cell Number and Diameter in Bovine Embryos Produced in vitro. Reproduction of Domestic Animals, 37, 181-4.

Nedambale, T. L., Dum, F., Yang, X., \& Tian, X. C. (2006). Higher survival rate of vitrified and thawed in vitro produced bovine blastocysts following culture in defined medium supplemented with beta-mercaptoethanol. Animal Reproduction Science, 93, 61-75. 
Research, Society and Development, v. 10, n. 14, e367101422097, 2021

(CC BY 4.0) | ISSN 2525-3409 | DOI: http://dx.doi.org/10.33448/rsd-v10i14.22097

Papaioannou, V. E., \& Ebert, K. M. (1988). The preimplantation pig embryo: cell number and allocation to trophectoderm and inner cell mass of the blastocyst in vivo and in vitro. Development, 102, 793-803.

Romek M, Gajda B, Krzysztofowicz E, \& Smorag Z. (2010). Changes of lipid composition in non-cultured and cultured porcine embryos. Theriogenology, 74, $265-76$.

Salzano A, Albero G, Zullo G, Neglia G, Abdel-Wahab A, Bifulco G, \& Zicarelli L, Gasparrini B. (2014). Effect of Resveratrol supplementation during culture on the quality and cryotolerance of bovine in vitro produced embryos. Animal Reproduction Science,151 (3-4), 91-6.

Sanches B. V., Zangirolamo A. F., \& Seneda M. M. (2019). Intensive use of IVF by large-scale dairy programs. Animal Reproduction, 16, $394-401$.

Silveira, M. M., Marques, T. C., Silva M. A. P., \& Leão K. M. (2020). Development stag e at packaging affects viability of in vitro produced bovine embryos. Research, Society and Development, 9: e13496361. http://dx.doi.org/10.33448/rsd-v9i6.3615

Sovernigo, T C., Adona, P. R, Monzani, P. S., Guemra, S, Barros, F, Lopes, F. G., \& Leal, C. (2017). Effects of supplementation of medium with different antioxidants during in vitro maturation of bovine oocytes on subsequent embryo production. Reproduction of Domestic Animals, 52, 561-9.

Sprícigo, J. F., Morató, R, Arcarons, N., Yeste, M., Dode, M. A., López-Bejar, M., \& Mogas, T. (2017). Assessment of the effect of adding L-carnitine and/or Resveratrol to maturation medium before vitrification on in vitro-matured calf oocytes. Theriogenology, 89, 47-57.

Sudano, M. J., Caixeta, E. S., Paschoal, D. M., Martins, A., Machado, R., Buratini, J., \& Landim-Alvarenga, F. D. C. (2013). Cryotolerance and global geneexpression patterns of Bos taurus indicus and Bos taurus taurus in vitro- and in vivo-produced blastocysts. Reproduction, Fertility, Development, $26,1129-41$. https://doi.org/ 10.1071/RD13099

Taniyama, A., Watanabe, Y., Nishino, Y., \& Inoue, T. (2011). Assisted hatching of poor-quality bovine embryos increases pregnancy. Journal of Reproduction and Development, 57, 543-6.

Ufer, C., Wang, C. C., Borchert, B., Heydeck, D., \& Kuhn, H. (2010). Redox control in mammalian embryo development. Antioxidant Redox Sign, 13, 83375 .

Wang, F., Tian, X., Zhang, L., He, C., Ji, P., Li, Y., Tan, D., \& Liu, G. (2014). Beneficial effect of Resveratrol on bovine oocyte maturation and subsequent embryonic development after in vitro fertilization. Fertility and Sterility, 101, 577-86 10.1016/j.fertnstert.2013.10.041.

Yu, S., Long, H., Lyu, Q. F., Zhang, Q. H., Yan, Z. G., Liang, H. X., \& Qi, C. (2014). Protective effect of quercetin on the development of pre-implantation mouse embryos against hydrogen peroxide- induced oxida-tive injury. PLoS One, 9: e89520. 